CORRECTION

\title{
Correction to: Millimeter-scale vertical partitioning of nitrogen cycling in hypersaline mats reveals prominence of genes encoding multi-heme and prismane proteins
}

\author{
P. Maza-Márquez (D, M. D. Lee (iD, A. M. Detweiler and B. M. Bebout \\ (C) This is a U.S. government work and not under copyright protection in the U.S.; foreign copyright protection may apply 2021
}

The ISME Journal (2022) 16:1202; https://doi.org/10.1038/s41396-021-01180-w

Correction to: The ISME Journal https://doi.org/10.1038/s41396-02101161-z, published online 03 December 2021

Following the publication of this article it was noted that there were a number of typographical errors. These have now been corrected.

The conclusions of the article remain unchanged.

The original article has been corrected. (c) Open Access This article is licensed under a Creative Commons adaptation, distribution and reproduction in any medium or format, as long as you give appropriate credit to the original author(s) and the source, provide a link to the Creative Commons licence, and indicate if changes were made. The images or other third party material in this article are included in the article's Creative Commons licence, unless indicated otherwise in a credit line to the material. If material is not included in the article's Creative Commons licence and your intended use is not permitted by statutory regulation or exceeds the permitted use, you will need to obtain permission directly from the copyright holder. To view a copy of this licence, visit http://creativecommons. org/licenses/by/4.0/.

(c) This is a U.S. government work and not under copyright protection in the U.S.; foreign copyright protection may apply 2021 